\title{
Kompetensi Akuntansi Sumber Daya Manusia dan Kinerja Pegawai dengan Produktivitas sebagai Variabel Intervening
}

\author{
Ni Kadek Budi Arsani ${ }^{1}$ \\ Fakultas Ekonomi dan Bisnis \\ Universitas Udayana, Indonesia
}

\author{
Ni Ketut Rasmini² \\ Fakultas Ekonomi dan Bisnis \\ Universitas Udayana, Indonesia
}

\begin{abstract}
Surel : budiarsani01@gmail.com
\section{ABSTRAK}

Penelitian ini bertujuan untuk mengetahui pengaruh kompetensi akuntansi sumber daya manusia pada kinerja pegawai dengan produktivitas BUM Desa sebagai variabel intervening. Pengumpulan data dilakukan melalui kuesioner. Penelitian ini menggunakan pendekatan kuantitatif dengan sumber data primer dan data sekunder. Populasi dalam penelitian ini adalah seluruh BUM Desa di Kabupaten Gianyar. Sampel yang dalam penelitian ini adalah BUM Desa yang ada di Kabupaten Gianyar dengan metode purposive sampling. Teknik analisis yang digunakan adalah path analysis. Hasil pengujian menunjukkan bahwa kompetensi akuntansi sumber daya manusia berpengaruh positif terhadap produktivitas BUM Desa di Kabupaten Gianyar. Produktivitas BUM Desa berpengaruh positif terhadap kinerja pegawai pada BUM Desa Kabuapten Gianyar. Kompetensi akuntansi sumber daya manusia berpengaruh positif terhadap kinerja pegawai pada BUM Desa Kabuapten Gianyar. Kompetensi akuntansi sumber daya manusia berpengaruh positif terhadap kinerja pegawai melalui produktivitas pada BUM Desa Kabuapten Gianyar.
\end{abstract}

Kata Kunci: Kompetensi Akuntansi Sumber Daya Manusia; Produktivitas; Kinerja Pegawai.

\section{Human Resource Accounting Competence and Employee Performance with Productivity as an Intervening Variable}$$
\text { ABSTRACT }
$$

This study aims to determine the effect of human resource accounting competence on employee performance with BUM Desa productivity as an intervening variable. Data collection was done through a questionnaire. This study uses a quantitative approach with primary data sources and secondary data. The population in this study were all BUM Desa in Gianyar Regency. The sample in this research is BUM Desa in Gianyar Regency with purposive sampling method. The analysis technique used is path analysis. The test results show that human resource accounting competence has a positive effect on the productivity of BUM Desa in Gianyar Regency. The productivity of BUM Desa has a positive effect on employee performance at BUM Desa, Gianyar Regency. Human resource accounting competence has a positive effect on employee performance at BUM Desa Gianyar Regency. Human resource accounting competence has a positive effect on employee performance through productivity at BUM Desa, Gianyar Regency.
\end{abstract}

Keywords: Human Resource Accounting Competence; Productivity; Employee Performance.

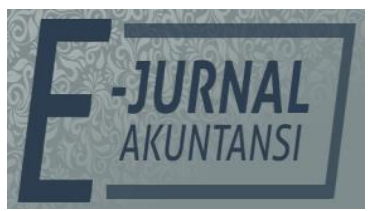

e-ISSN 2302-8556

Vol. 31 No. 9

Denpasar, September 2021 Hal. 2326-2339

DOI:

10.24843/EJA.2021.v31.i09.p14

PENGUTIPAN:

Arsani, N.K.B., \& Rasmini,

N.K. (2021). Kompetensi

Akuntansi Sumber Daya Manusia dan Kinerja Pegawai dengan Produktivitas sebagai Variabel Intervening. E-Jurnal Akuntansi, 31(9), 2326-2339

RIWAYAT ARTIKEL:

Artikel Masuk:

3 Agustus 2021

Artikel Diterima: 9 September 2021

Artikel dapat diakses : https://ojs.unud.ac.id/index.php/Akuntansi/index 


\section{PENDAHULUAN}

Undang-Undang Nomor 6 Tahun 2014 tentang Desa menjelaskan bahwa Badan Usaha Milik Desa, yang selanjutnya di sebut BUM Desa, adalah badan usaha yang seluruh atau sebagian besar modalnya dimiliki oleh Desa melalui penyertaan secara langsung yang berasal dari kekayaan Desa yang dipisahkan guna mengelola aset, jasa pelayanan, dan usaha lainnya untuk sebesar-besarnya kesejahteraan masyarakat Desa. Tujuan didirikannya BUM Desa untuk mengoptimalkan perekonomian dan aset desa, meningkatkan pendapatan desa, serta mengingkatkan kesejahteraan masyarakat melalui pelayanan umum. Pengelolaan BUM Desa sepenuhnya oleh masyarakat dan pemerintahan desa. BUM Desa tentu memerlukan laporan keuangan dengan tujuan menyajikan informasi mengenai posisi keuangan, realisasi anggaran, arus kas dan kinerja keuangan suatu entitas pelaporan yang bermanfaat bagi para pengguna dalam membuat dan mengevaluasi keputusan mengenai alokasi sumber daya (Irawan \& Martanti, 2017).

Laporan keuangan merupakan hasil akhir dari suatu proses pencatatan transaksi keuangan perusahaan yang memberi gambaran kondisi keuangan perusahaan pada satu periode akuntansi dan mengenai kinerja suatu perusahaan (Margaretha \& Nababan, 2020). Tujuan laporan keuangan adalah memberikan informasi mengenai posisi keuangan, kinerja keuangan dan arus kas entitas yang bermanfaat bagi sebagian besar kalangan pengguna laporan dalam pembuatan keputusan ekonomi. Hasil audit pada laporan keuangan harus memenuhi tiga kriteria pengukuran, salah satunya adalah efisiensi, yang berarti output dari organisasi dimaksimalkan atas setiap penggunaan sumber daya organisasi, yang dalam hal ini output BUM Desa adalah kinerja pegawai (Bastian, 2007:129).

Kinerja karyawan pada dasarnya adalah hasil kerja karyawan selama periode tertentu (Supriyanto et al., 2021). Kinerja merupakan suatu hasil dari kerja secara kualitas dan kuantitas yang dicapai oleh pegawai. Definisi kinerja secara sederhana adalah sejauh mana pekerjaan dilakukan dengan baik dan optimal (Wibowo et al., 2020). Permasalahan pokok BUM Desa adalah kualitas kinerja sumber daya manusia yang masih rendah. Kinerja sumber daya manusia yang dimaksud adalah kinerja karyawan BUM Desa. Karyawan BUM Desa sekaligus merangkap sebagai pengelola terdiri dari ketua, sekretaris dan bendahara. Tinggi rendahnya tingkat kinerja karyawan dan pengelola lembaga akan berpengaruh terhadap kinerja lembaga, ini menunjukkan bahwa BUM Desa memerlukan sumber daya yang berkompeten untuk meningkatkan kinerja karyawan (Swandari et al., 2017). Kompetensi interpersonal pada sumber daya manusia secara luas diakui sebagai kunci dalam menunjang kinerja (Konrad et al., 2021). Pengembangan kompetensi yang dimiliki sumber daya manusia merupakan proses yang kreatif dan diperoleh melalui pengalaman sehingga dapat meningkatkan kinerja dengan menciptakan ide baru untuk organisasi (Abdivalievna et al., 2021). Hal ini sejalan dengan penelitian yang dilakukan Mogot et al., (2019) dan Saleh \& Lakhal (2018) dimana hasilnya menunjukan kompetensi sumber daya manusia dalam aspek prestasi berpengaruh positif terhadap kinerja karyawan.

Kompetensi diperlukan untuk mengefesiensikan pekerjaan guna mencapai tujuan organisasi yaitu produktivitas. Produktivitas menurut Hasibuan (1996) 
adalah perbandingan antara output (hasil) dengan input (masukan). Produktivitas tercapai apabila terjadi peningkatan efisiensi (waktu, bahan, maupun tenaga), sistem kerja, teknik produksi, dan adanya peningkatan keterampilan pegawai (Elbadiansyah, 2019:250). Apabila produktivitas suatu organisasi tercapai maka kinerja pegawai dinyatakan baik. Sehingga kinerja tidak hanya dipengaruhi secara langsung oleh kompetensi SDM yang bersangkutan namun juga dipengaruhi oleh produktivitas organisasi.

Pengelolaan aset desa terbaik tahun 2018 menurut Indeks Desa Membangun (IDM) di Provinsi Bali diperoleh oleh Desa Peliatan yang merupakan salah satu desa yang terletak di Kabupaten Gianyar (Republika.co.id (6/6/19). Kepala Desa Peliatan I Made Dwi Sutaryantha menyatakan sekitar Rp1.000.000.000,00 dana desa telah diterima dari pemerintah. Dana desa tersebut digunakan untuk mendukung upaya penguatan sosial ekonomi dan pelestarian adat serta budaya. Berdasarkan tujuan dari pendirian BUM Desa yaitu mengoptimalkan pengelolaan aset desa untuk kesejahteraan masyarakat desa, maka Desa Peliatan memanfaatkan dana desa untuk memodali kegiatan dan inovasi usaha warga. Sekitar Rp150.000.000,00 atau 15\% dari dana desa tersebut diterima oleh BUM Desa Praja Krta Laksmi setiap tahunnya untuk disalurkan sebagai modal usaha mikro bagi warga.

Teori Atribusi (attribution theory) merupakan suatu teori yang membahas bagaimana individu menarik kesimpulan tentang penyebab dari suatu perilaku baik perilaku dari dirinya sendiri maupun dari orang lain bahkan organisasi (Kriyantono, 2017:171). Singkatnya teori ini berusaha menjelaskan bagian mengapa dari suatu perilaku dan perilaku manusia dipelajari dalam ilmu psikologi. Teori Motivasi Komptensi dikemukakan oleh Robert White, yang menyatakan bahwa setiap manusia mempunyai keinginan untuk menujukkan kompetensi dengan menaklukkan lingkungannya. Motivasi belajar pada seseorang merupakan dorongan internal ke tingkah laku yang membawanya kearah kemampuan dan penguasaan (Hasanuddin, 2017:453-454). Adapun kerangka konseptual dalam penelitian ini dapat dilihat pada Gambar 1.



Gambar 1. Kerangka Konseptual

Sumber: Data Penelitian, 2021 
Menurut Supriyono (2018) akuntansi sumber daya manusia adalah akuntasi yang menjadikan manusia sebagai salah satu sumber daya dalam suatu organisasi. Hal ini tentu mendukung teori atribusi yang menyatakan bahwa perilaku seseorang didorong atas kekuatan internal (internal forces) yaitu kemampuan dan pengetahuan. Selain itu juga mendukung teori motivasi kompetensi yang menyatakan bahwa setiap individu akan berusaha untuk menaklukkan lingkungan dengan kompetensi yang dimiliki. Hasil penelitian ini mendukung penelitian sebelumnya yang dilakukan oleh Abubakar (2018) yang menyatakan bahwa kompetensi berpengaruh positif terhadap produktivitas. Sejalan dengan penelitian yang dilakukan Rani et al., (2018), Tumiwa et al., (2017), Hidayah \& Nurbaiti (2019), Vveinhardt et al., (2019), dan Rusilowati \& Maulida (2020).

$\mathrm{H}_{1}$ : Kompetensi akuntansi sumber daya manusia berpengaruh positif terhadap produktivitas BUM Desa.

Menurut Hasibuan (1996), produktivitas adalah perbandingan antara output (hasil) dengan input (masukan). Produktivitas tercapai apabila terjadi peningkatan efisiensi (waktu, bahan, maupun tenaga), sistem kerja, teknik produksi, dan adanya peningkatan keterampilan pegawai. Konsisten untuk meningkatkan produktivitas akan memberikan dampak yang baik terhadap kinerja. Hal ini mendukung pernyataan teori atribusi yang menyatakan bahwa suatu proses dimana individu berusaha menjelasakan alasan dari suatu peristiwa. Hasil penelitian ini mendukung penelitian yang dilakukan oleh Marzuki \& Wair (2020) dan Iskandar (2018) yang menyatakan bahwa produktivitas berpengaruh positif terhadap kinerja pegawai.

$\mathrm{H}_{2}$ : Produktivitas BUM Desa berpengaruh positif terhadap kinerja pegawai.

Akuntansi sumber daya manusia mengakui bahwa manusia adalah modal manusia atau aset manusia. Karyawan yang berkompeten dengan memiliki pengetahuan dan ketrampilan yang kuat, tentu akan mampu untuk menyelesaikan pekerjaannya dan menghadapi tantangan baru sesuai tuntutan kerja. Hal ini mendukung teori atribusi yang menyatakan bahwa perilaku seseorang timbul dari kekuatan internal yaitu kemampuan. Merupakan suatu jaminan apabila sumber daya manusia berkompeten dalam bidangnya tentu akan memberikan dampak yang baik untuk kinerja pegwai. Hal ini mendukung penelitian yang dilakukan oleh Yuliantini et al., (2017) yang menyatakan bahwa kompetensi berpengaruh positif terhadap kinerja pegwai. Sejalan dengan penelitian yang dilakukan oleh Arifin et al., (2019), Anggraeni \& Helmy (2020), dan Ahmed \& Anantatmula (2017).

$\mathrm{H}_{3}$ : Kompetensi akuntansi sumber daya manusia berpengaruh positif terhadap kinerja pegawai BUM Desa.

Pentingnya kemampuan atau kompetensi yang dimiliki oleh sumber daya manusia diyakini mampu memberikan peningkatan pada kinerja. Hal ini sejalan dengan teori atribusi yang dikembangkan oleh Heider menjelaskan mengenai perilaku seseorang mengacu tentang bagaimana seseorang menjelaskan penyebab perilaku orang lain atau bahkan dirinya sendiri yang disebabkan oleh faktor internal yaitu kemampuan dan faktor eskternal yaitu lingkungan kerja. Hal ini sejalan dengan penelitian yang dilakukan oleh Yuliantini et al., (2017) menyatakan bahwa kualitas SDM merupakan salah satu faktor yang diperlukan untuk meningkatkan kinerja suatu organisasi. Penelitian Anggraeni \& Helmy (2020) dan 
Ahmed \& Anantatmula (2017) juga menyatakan bahwa kompetensi berpengaruh positif terhadap kinerja.

$\mathrm{H}_{4}$ : Kompetensi akuntansi sumber daya manusia berpegaruh positif pada kinerja pegawai melalui produktivitas BUM Desa.

\section{METODE PENELITIAN}

Lokasi penelitian dilakukan di Kabupaten Gianyar, Bali. Obyek dalam penelitian ini adalah pegawai BUM Desa se Kabupaten Gianyar yang mendalami bidang keuangan dan pemimpin. Penelitian ini menggunakan metode survey dengan teknik kuesioner. Pengukuran variabel dalam penelitian ini menggunakan skala likert yang ditemukan oleh Rensis Likert. Sumber data dalam penelitian ini adalah data kualitatif dan kuantitatif. Populasi yang digunakan dalam penelitian ini adalah seluruh BUM Desa terdapat di Kabupaten Gianyar sejumlah 58 unit dari 64 desa. Dilihat dari indikator banyaknya BUM Desa di Kabupaten Gianyar, pengambilan sampel dalam penelitian ini menggunakan metode purposive sampling. Adapun pertimbangan penentuan sampel dalam penelitian ini, yaitu, (a) merupakan pegawai BUM Desa (b) ketua BUM Desa, menaungi bidang akuntansi/keuangan, dan sekretaris, (c) pengalaman bekerja minimal satu tahun.

Uji validitas dilakukan dengan menggunakan bantuan program SPSS. Kuisioner dikatakan valid apabila pertanyaan pada kuisioner mampu untuk mengungkapkan sesuatu yang diukur kuisioner tersebut. Uji reliabilitas dilakukan secara bersama-sama terhadap seluruh pernyataan dengan bantuan SPSS. Suatu kuisioner dinyatakan reliabel atau handal jika jawaban semua responden itu terhadap pertanyaan adalah konsisten atau stabil dari waktu ke waktu atau jika memberikan nilai Cronbach Alpha > 0.70 (Ghozali, 2016 : 47-48).

Pengujian pengaruh variabel intervening digunakan metode analisis jalur (Path Analysis). Asumsi dasar model ini adalah beberapa variabel sebenarnya mempunyai hubungan yang sangat dekat satu dengan yang lainnya. Adapun persamaan regresi dalam penelitian ini adalah sebagai berikut.

$Z=\alpha+\beta_{1} X+\varepsilon$

$Y=\alpha+\beta_{1} X+\beta_{2} Z+\varepsilon$

Keterangan:

$\mathrm{Z} \quad=$ Produktivitas BUM Desa

$\mathrm{Y} \quad=$ Kinerja Pegawai

a $\quad=$ Konstanta

$\beta_{1} \mathrm{X} \quad=$ Koefisien Regresi Kompetensi ASDM

$\beta_{2} \mathrm{Z}=$ Koefisien Regresi Produktivitas BUM Desa

$\varepsilon \quad=$ Residual

Uji sobel merupakan suatu uji dengan cara menguji ada atau tidaknya pengaruh tidak langsung variabel independent $(X)$ kepada variabel dependent $(Y)$ melalui variabel intervening (M) (Riyanto \& Hatmawan, 2020: 219). Adapun dasar ketentuan nilai uji sobel yaitu $z$-value $>1,96$ atau $p$-value $<\alpha=0,05$. Pengujian uji sobel dapat dilakukan dengan empat tahap, sebagai berikut. Adapun rumus uji sobel sebagai berikut.

$S a b=\sqrt{b^{2} \cdot \mathrm{sea}^{2}+\mathrm{a}^{2} \cdot \mathrm{seb}^{2}+\mathrm{seb}^{2} \cdot \mathrm{sea}^{2}}$ 


\section{HASIL DAN PEMBAHASAN}

Badan Usaha Milik Desa (BUM Desa) di Kabupaten Gianyar mulai pertama kali terbentuk tahun 2013 pada tiga desa yaitu Desa Lebih, Taro, dan Buahan Kaja. Dilanjutkan pada tahun 2014-2016 berdiri sebanyak 15 BUM Desa yakni di Desa Buahan, Babakan, Sumita, Siangan, Keliki, Pupuan, Kerta, Puhu, Bukian, Kemenuh, Petak, Sidan, Manukaya, Pejeng Kangin, dan Batubulan. Tahun 20172019 mengalami peningkatan pesat yakni sejumlah 40 BUM Desa yang tersebar di seluruh kecamatan di Kabupaten Gianyar. Hingga kini sudah terbentuk 58 BUM Desa di Kabupaten Gianyar dengan 3 BUM Desa yang tidak aktif yaitu Desa Pejeng Kangin, Melinggih, dan Medahan. Berdasarkan data penelitian yang dilakukan dari penyebaran kuesioner maka diperoleh data mengenai jenis kelamin responden yang dapat dilihat pada Tabel 1, berikut ini.

Tabel 1. Karakteristik Responden menurut Jenis Kelamin pada Pegawai BUM Desa di Kabupaten Gianyar

\begin{tabular}{cccc}
\hline No. & Jenis Kelamin & Jumlah (orang) & Jumlah (persentase) \\
\hline 1. & Laki-laki & 57 & 41,61 \\
2. & Perempuan & 80 & 58,39 \\
& Jumlah & 137 & 100 \\
\hline
\end{tabular}

Sumber: Data Penelitian, 2021

Berdasarkan Tabel 1, dapat diketahui bahwa sebagian besar responden sebanyak 57 orang dengan persentase 41,61 persen adalah laki-laki dan 80 orang responden dengan persentase 58,39 persen adalah perempuan. Hal ini berarti bahwa sebagian besar responden yakni sebanyak 80 orang dengan persentase 58,39 persen berjenis kelamin perempuan.

Latar belakang pendidikan yang dimiliki seseorang akan mempengaruhi segi pola pikir, sikap dan tingkah laku sehingga memiliki kontribusi yang besar untuk organisasi (Pitriyanti \& Halim, 2020). Berdasarkan data penelitian yang diperoleh dari penyebaran kuesioner maka diperoleh data tentang pendidikan terakhir responden yang dapat dilihat pada Tabel 2. berikut.

Tabel 2. Karakteristik Responden menurut Pendidikan pada Pegawai BUM Desa di Kabupaten Gianyar

\begin{tabular}{cccc}
\hline No. & Tingkat Pendidikan & Jumlah (orang) & Persentase \\
\hline 1 & S2 & 2 & 1,46 \\
2 & S1 & 54 & 39,42 \\
3 & D4 & 5 & 3,65 \\
4 & D3 & 4 & 2,92 \\
5 & D2 & 6 & 4,38 \\
6 & D1 & 5 & 3,65 \\
7 & SMK & 17 & 12,41 \\
8 & SMA & 44 & 32,12 \\
& Total & 137 & 100 \\
\hline
\end{tabular}

Sumber: Data Penelitian, 2021

Berdasarkan Tabel 2, dapat diketahui bahwa sebagian besar responden sebanyak 54 orang berpendidikan S1 orang berpendidikan SMA dan 2 orang berpendidikan S2 yang menduduki urutan dengan persentase terkecil. Berdasarkan data penelitian yang dilakukan dari penyebaran kuesioner maka 
diperoleh data tentang bagian responden dalam perusahaan yang dapat dilihat pada Tabel 3, berikut.

Tabel 3. Karakteristik Responden menurut Bagian Pekerjaan pada BUM Desa Kabupaten Gianyar

\begin{tabular}{cccc}
\hline No. & Bagian Pekerjaan & Jumlah (orang) & Persentase \\
\hline 1 & Ketua & 53 & 38,69 \\
2 & Bendahara & 52 & 37,96 \\
3 & Sekretaris & 32 & 23,36 \\
& Jumlah & 137 & 100 \\
\hline
\end{tabular}

Sumber: Data Penelitian, 2021

Berdasarkan Tabel 3, dapat diketahui bahwa sebanyak 53 orang responden dengan persentase 38,69 persen menduduki jabatan sebagai ketua, 52 orang responden dengan persentase 37,96 persen menduduki jabatan sebagai bendahara, dan 32 orang responden dengan persentase 23,36 persen menduduki jabatan sebagai sekretaris. Hal ini berarti bahwa sebagian besar responden sebanyak 53 orang menduduki jabatan sebagai ketua dan sebanyak 32 orang menduduki jabatan sebagai sekretaris yang menduduki urutan dengan persentase terkecil. Jumlah kuesioner yang disebarkan adalah sebanyak 174 lembar kuesioner. Sedangkan kuesioner yang dapat diolah sebanyak 137 kuesioner dengan persentase $79 \%$ dan kuesioner yang tidak dapat diolah sebanyak 37 kuesioner dengan persentase $21 \%$. Kuesioner tidak dapat digunakan karena terdapat BUM Desa yang sudah tidak beroperasi sehingga kuesioner kosong dan terdapat kuesioner yang tidak sesuai dengan kriteria.

Berdasarkan hasil penelitian Rata-rata skor dari 11 item pernyataan mengenai kompetensi akuntansi sumber daya manusia adalah sebesar 3,313. Nilai rata-rata tertinggi terdapat pada pernyataan 8 yaitu Rekan kerja saya sangat profesional dalam bekerja sesuai dengan kode etik sebagai seorang akuntan., sebesar 3,416 dengan rincian 16 orang menjawab tidak setuju, 48 orang menjawab setuju, dan 73 orang menjawab sangat setuju. Hal tersebut menunjukkan bahwa rekan kerja dalam bidang akuntansi atau keuangan sangat mematuhi kode etik sebagai seorang akuntan. Nilai rata-rata terendah terdapat pada pernyataan 2 yaitu Pengalaman yang dimiliki rekan saya dapat dengan mudah menyelesaikan pekerjaan., sebesar 3,168 dengan rincian 17 orang menjawab tidak setuju, 80 orang menjawab setuju dan 40 orang menjawab sangat setuju. Hal tersebut menunjukkan bahwa pengalaman yang dimiliki sesama rekan kerja di BUM Desa Kabupaten Gianyar tidak dapat dengan mudah menyelesaikan pekerjaan khususnya pada kompetensi akuntansi.

Berdasarkan hasil pemelitian rata-rata skor dari 7 item pernyataan mengenai kinerja pegawai adalah sebesar 3,316. Nilai rata-rata tertinggi terdapat pada pernyataan 3 yaitu Saat rapat rekan saya selalu memberikan pendapat baik masukan maupun kritik yang bersifat membangun. Sebesar 3,533 dengan rincian 16 orang menjawab tidak setuju, 72 orang menjawab setuju, dan 48 orang menjawab sangat setuju. Hal tersebut menunjukkan bahwa sesama rekan kerja selalu memberikan pendapat baik masukan maupun kritik yang bersifat membangun tanpa harus menjatuhkan. Nilai rata-rata terendah terdapat pada pernyataan 2 yaitu Rekan kerja saya sangat teliti dalam bekerja, sebesar 3,088 dengan rincian 20 orang menjawab tidak setuju, 85 orang menjawab setuju dan 32 
orang menjawab sangat setuju. Hal tersebut menunjukkan bahwa kinerja pegawai masih belum optimal dalam dalam hal ketelitian.

Berdasarkan hasil penelitian, rata-rata skor dari 7 item pernyataan mengenai kinerja pegawai adalah sebesar 3,263. Nilai rata-rata tertinggi terdapat pada pernyataan 5 yaitu Rekan saya selalu belajar dari pengalaman untuk mengurangi kesalahan, sebesar 3,401 dengan rincian 20 orang menjawab tidak setuju, 42 orang menjawab setuju, dan 72 orang menjawab sangat setuju. Hal tersebut menunjukkan bahwa pegawai BUM Desa selalu belajar dari pengalaman untuk mengurangi kesalahan. Nilai rata-rata terendah terdapat pada pernyataan 2 yaitu Dalam bekerja rekan saya selalu melakukan yang terbaik, sebesar 3,161 dengan rincian 4 orang menjawab tidak setuju, 107 orang menjawab setuju dan 26 orang menjawab sangat setuju. Hal tersebut menunjukkan bahwa dalam bekerja belum melakukan yang terbaik.

Hasil Uji Validitas menunjukkan bahwa indikator penelitian yang digunakan untuk mengukur variabel kompetensi akuntansi sumber daya manusia, kinerja pegawai, dan produktivitas BUM Desa memiliki nilai koefisien korelasi dengan skor total seluruh butir pernyataan lebih besar dari 0,30 dengan nilai signifikansi lebih kecil dari 0,05. Hal ini menunjukkan bahwa butir-butir pernyataan dalam instrumen penelitian tersebut valid dan layak digunakan sebagai instrumen penelitian. Hasil uji reliabilitas menunjukkan bahwa nilai Cronbach's Alpha untuk setiap variabel lebih besar dari 0,6. Jadi dapat dinyatakan bahwa seluruh variabel telah memenuhi syarat reliabilitas atau kehandalan.

Asumsi dasar model ini adalah beberapa variabel sebenarnya mempunyai hubungan yang sangat dekat satu dengan yang lainnya. Analisis ini dilakukan dengan tahapan sebagai berikut. Dari hasil perhitungan pada pengujian data diperoleh hasil pada Tabel 4.

Tabel. 4 Model Summary dan Coefficients Substruktur 1

\begin{tabular}{|c|c|c|c|c|c|c|}
\hline \multirow{3}{*}{\multicolumn{2}{|c|}{ Model }} & \multicolumn{5}{|c|}{ Standardized } \\
\hline & & \multicolumn{2}{|c|}{ Unstandardized Coefficients } & Coefficients & $T$ & Sig. \\
\hline & & $B$ & Std. Error & Beta & & \\
\hline \multirow[t]{2}{*}{1} & (Constant) & 10,991 & 2,534 & & 4,337 & 0,00 \\
\hline & $X$ & 0,335 & 0,069 & 0,387 & 4,878 & 0,00 \\
\hline \multicolumn{2}{|c|}{$\mathrm{R}$} & $=0,387$ & & & & \\
\hline \multicolumn{2}{|c|}{ R Square } & $=0,150$ & & & & \\
\hline \multicolumn{2}{|c|}{ Adjusted R Square } & $=0,144$ & & & & \\
\hline \multicolumn{2}{|c|}{ Anova Sig. } & $=0,000$ & & & & \\
\hline
\end{tabular}

a. Dependent Variable: $\mathrm{Z}$

Sumber: Data Penelitian, 2021

Berdasarkan perhitungan terhadap substruktur 1 dan 2, maka dapat diketahui besarnya pengaruh langsung, pengaruh tidak langsung dan pengaruh total antar variabel. Perhitungan pengaruh antar variabel adalah sebagai berikut. Dari hasil perhitungan pada pengujian data diperoleh hasil pada Tabel 5.

Besarnya pengaruh langsung (Direct effect / DE) variabel gaya kepemimpinan, dan lingkungan kerja terhadap motivasi secara parsial, serta pengaruh variabel gaya kepemimpinan, dan lingkungan kerja terhadap komitmen secara parsial dilihat dari nilai beta atau Standardized Coefficient adalah sebagai berikut. (a) Pengaruh variabel kompetensi akuntansi sumber daya manusia terhadap produktivitas BUM Desa sebesar 0,387, (b) Pengaruh variabel 
produktivitas BUM Desa terhadap kinerja pegawai sebesar 0,414, (c) Pengaruh variabel kompetensi akuntansi sumber daya manusia terhadap kinerja pegawai sebesar 0,359. Besarnya pengaruh tidak langsung (Indirect effect / IE) pada variabel kompetensi akuntansi akuntansi sumber daya manusia terhadap kinerja pegawai melalui produktivitas BUM desa sebesar $(0,387 \times 0,414)=0,160$.

Tabel 5. Model Summary dan Coefficients Substruktur 2

\begin{tabular}{|c|c|c|c|c|c|c|}
\hline \multicolumn{2}{|c|}{ Model } & \multicolumn{2}{|c|}{$\begin{array}{l}\text { Unstandardized } \\
\text { Coefficients }\end{array}$} & \multicolumn{2}{|c|}{$\begin{array}{c}\text { Standardized } \\
\text { Coefficients }\end{array}$} & \multirow[t]{2}{*}{ Sig. } \\
\hline & & $B$ & Std. Error & Beta & $T$ & \\
\hline \multirow[t]{3}{*}{1} & (Constant) & 9,245 & 1,462 & & 6,322 & 0,000 \\
\hline & $X$ & 0,202 & 0,040 & 0,359 & 5,008 & 0,000 \\
\hline & Z & 0,269 & 0,047 & 0,414 & 5,776 & 0,000 \\
\hline $\mathrm{R}$ & $=0,644$ & & & & & \\
\hline R Square & $=0,415$ & & & & & \\
\hline Adjusted $R$ & $=0,406$ & & & & & \\
\hline $\begin{array}{l}\text { Anova Sig. } \\
\text { a. Depend }\end{array}$ & $\begin{array}{l}=0,000 \\
\text { iable: } Y\end{array}$ & & & & & \\
\hline
\end{tabular}

Sumber: Data Penelitian, 2021

Uji sobel merupakan suatu uji dengan cara menguji ada atau tidaknya pengaruh tidak langsung variabel independent $(X)$ kepada variabel dependent $(Y)$ melalui variabel intervening (M) (Riyanto \& Hatmawan, 2020:219). Adapun dasar ketentuan nilai uji sobel yaitu $z$-value $>1,96$ atau $p$-value $<\alpha=0,05$. Berdasarkan hasil perhitungan tersebut diketahui bahwa nilai $z$ hitung sebesar 3,669. Karena $z$ hitung sebesakerangr 3,669 > 1,96 dapat disimpulkan bahwa pengaruh tidak langsung signifikan.

Hipotesis pertama dalam penelitian ini menyatakan bahwa kompetensi akuntansi sumber daya manusia berpengaruh positif terhadap Produktivitas BUM Desa. Hasil pengujian menunjukkan bahwa nilai koefisien path analysis variabel kompetensi akuntansi sumber daya manusia bernilai positif sebesar 0,387 dengan nilai signifikansi sebesar 0,000. Nilai signifikansi sebesar 0,000 $<0,05$ sehingga $\mathrm{H}_{1}$ diterima. Hal ini menunjukkan bahwa kompetensi akuntansi sumber daya manusia berpengaruh positif terhadap produktivitas BUM Desa. Mendukung teori atribusi yang menyatakan bahwa perilaku seseorang didorong atas kekuatan internal (internal forces) yaitu kemampuan dan teori motivasi kompetensi yang menyatakan bahwa setiap individu akan berusaha untuk menaklukkan lingkungan dengan kompetensi yang dimiliki. Berdasarkan pendapat tersebut apabila kompetensi akuntansi sumber daya manusia optimal maka produktivitas BUM Desa akan meningkat. Hasil penelitian ini mendukung penelitian sebelumnya yang dilakukan oleh Abubakar (2018), Rani et al., (2018), Tumiwa et al., (2017), Hidayah \& Nurbaiti (2019), Vveinhardt et al., (2019), dan Rusilowati \&Maulida (2020) yang menyatakan bahwa kompetensi berpengaruh positif terhadap produktivitas.

Hipotesis kedua dalam penelitian ini menyatakan bahwa produktivitas BUM Desa berpengaruh positif terhadap kinerja pegawai. Hasil pengujian menunjukkan bahwa nilai koefisien path analysis variabel produktivitas BUM Desa bernilai positif sebesar 0,414 dengan nilai s signifikansi sebesar 0,000. Nilai signifikansi sebesar $0,000<0,05$ sehingga $\mathrm{H}_{1}$ diterima. Hal ini menunjukkan bahwa produktivitas BUM Desa berpengaruh positif terhadap kinerja pegawai. 
Produktivitas tercapai apabila terjadi peningkatan efisiensi (waktu, bahan, maupun tenaga), sistem kerja, teknik produksi, dan adanya peningkatan keterampilan pegawai. Meningkatnya produktivitas suatu organisasi merupakan cerminan dari kinerja pegawai yang baik. Sejalan dengan penelitian Marzuki \& Wair (2020) dan Iskandar (2018) yang menyatakan bahwa produktivitas berpengaruh positif terhadap kinerja pegawai.

Hipotesis ketiga dalam penelitian ini menyatakan bahwa kompetensi akuntansi sumber daya manusia berpengaruh positif terhadap kinerja pegawai. Hasil pengujian menunjukkan bahwa nilai koefisien path analysis variabel produktivitas BUM Desa bernilai positif sebesar 0,359 dengan nilai signifikansi sebesar 0,000 . Nilai signifikansi sebesar $0,000<0,05$ sehingga $\mathrm{H}_{1}$ diterima. Hal ini menunjukkan bahwa kompetensi akuntansi sumber daya manusia berpengaruh positif terhadap kinerja pegawai. Akuntansi sumber daya manusia mengakui bahwa manusia adalah modal manusia atau aset manusia. Sumber daya manusia merupakan salah satu faktor yang diperlukan untuk meningkatkan kinerja suatu organisasi. Merupakan suatu jaminan apabila sumber daya manusia berkompeten dalam bidangnya tentu akan memberikan dampak yang baik untuk kinerja pegawai. Hal ini mendukung penelitian yang dilakukan oleh Yuliantini (2017) yang menyatakan bahwa kompetensi berpengaruh positif terhadap kinerja pegwai. Sejalan dengan penelitian yang dilakukan oleh Arifin et at., (2019), Anggraeni \& Helmy (2020) dan Ahmed \& Anantatmula (2017).

Hipotesis keempat dalam penelitian ini menyatakan bahwa kompetensi akuntansi sumber daya manusia pada kinerja pegawai melalui produktivitas BUM Desa. Hasil pengujian sobel menunjukkan bahwa z-value sebesar 3,669 > z-tabel $(1,96)$ dengan nilai signifikansi sebesar 0,000 sehingga terdapat pengaruh tidak langsung yang signifikan. Nilai signifikansi sebesar 0,000 $<0,05$ sehingga $\mathrm{H}_{1}$ diterima. Hal ini menunjukkan bahwa kompetensi akuntansi sumber daya manusia pada kinerja pegawai melalui produktivitas BUM Desa. Kompetensi mengefesiensikan pekerjaan untuk mencapai produktivitas. Produktivitas tercapai apabila terjadi peningkatan efisiensi (waktu, bahan, maupun tenaga), sistem kerja, teknik produksi, dan adanya peningkatan keterampilan pegawai. Apabila produktivitas suatu organisasi meningkat maka kinerja pegawai tentu akan meningkat. Sehingga kinerja tidak hanya dipengaruhi secara langsung oleh kompetensi SDM yang bersangkutan namun juga dipengaruhi oleh produktivitas organisasi Yuliantini (2017), Anggraeni \& Helmy (2020), Ahmed \& Anantatmula (2017), Marzuki \& Wair (2020) dan Iskandar (2018).

\section{SIMPULAN}

Kompetensi akuntansi sumber daya manusia berpengaruh positif terhadap produktivitas BUM Desa di Kabupaten Gianyar. Semakin baik kompetensi akuntansi sumber daya manusia dan semakin optimal, baik dari segi pengetahuan, kemampuan maupun sikap yang mencerminkan produktivitas kerja maka akan memberikan dampak baik terhadap produktivitas organisasi. Produktivitas BUM Desa berpengaruh positif terhadap kinerja pegawai pada BUM Desa Kabupaten Gianyar. Semakin baik produktivitas suatu organisasi, efisiensi (waktu, bahan, maupun tenaga), sistem kerja, teknik produksi, dan adanya peningkatan keterampilan pegawai maka semakin baik kinerja pegawai. 
Kompetensi akuntansi sumber daya manusia berpengaruh positif terhadap kinerja pegawai pada BUM Desa Kabupaten Gianyar. Semakin baik kompetensi akuntansi sumber daya manusia, semakin kuat pengetahuan dan keterampilan yang dimiliki pegawai dalam suatu organisasi maka semakin baik kinerja pegawai suatu organisasi. Kompetensi akuntansi sumber daya manusia berpengaruh positif terhadap kinerja pegawai melalui produktivitas BUM Desa Kabupaten Gianyar. Semakin berkompeten pegawai dalam bekerja, maka kinerja pegawai akan semakin baik, dan secara tidak langsung produktivitas BUM Desa yang optimal juga dapat meningkatkan kinerja pegawai.

Bagi BUM Desa Kabupaten Gianyar disarankan untuk mengadakan program pelatihan khususnya pada bidang keuangan atau akuntansi untuk memudahkan menjalankan pekerjaan dan adanya kesetaraan laporan keuangan antara satu BUM Desa dengan BUM Desa lainnya, diharapkan lebih teliti dalam melakukan pekerjaan karena ketelitian merupakan hal yang penting untuk meminimalisir kesalahan dalam bekerja dengan berpikir secara logis, kritis, dan kreatif, dan meyakinkan pegawainya bahwa setiap pekerjaan ataupun tugas lainnya sudah menjadi keharusan melakukan yang terbaik untuk mencapai produktivitas yang optimal. Bagi Peneliti selanjutnya disarankan untuk menambahkan variabel dalam penelitian ini mengingat penunjang kinerja tidak hanya berdasarkan kompetensi akuntansi sumber daya manusia ataupun produktivitas. Peneliti selanjutnya juga disarankan untuk memcari wilayah penelitian di kabupaten lainnya sehingga terdapat komparasi antara BUM Desa Kabupaten Gianyar dengan kabupaten lainnya.

\section{REFERENSI}

Abdivalievna, K. O. (2021). The Features Of Critical Thinking In Improving Students' Intercultural Competence, 8:5, pp. 375-381.

Abubakar, R. R. T. (2018). Pengaruh Kompetensi Pegawai Terhadap Produktivitas Kerja Pegawai Dinas Kesehatan Kota Bandung. Jurnal Administrasi Negara, 24 (1), hal. 17-32. https:// doi.org/10.33509/jan.v24i1.63.

Afandi, Pandi. (2016). Concept \& Indicator Human Resources Management for Management Research. Yogyakarta: CV Budi Utama.

Ahmed, R., \& Anantatmula, V. S. (2017). Empirical Study of Project Managers Leadership Competence and Project Performance. EMJ - Engineering Management Journal, 29:3, pp. 189-205. https:/ / doi.org/10.1080/10429247.2017.1343005.

Ansori, Muslich., \& Iswati, Sri. (2017). Metode Penelitian Kuantitatif Edisi 2. Surabaya: Airlangga University Press.

Arifin, S., Putra, A. R., \& Hartanto, C. F. B. (2019). Pengaruh Kompetensi, Kompensasi dan Kepemimpinan Terhadap Kinerja Karyawan. Ekonomi, Keuangan, Investasi Dan Syariah (EKUITAS), 1 (1), hal. 22-29.

Ariyanti, N. S., Wiyono, B. B., Timan, A., Burhanuddin, B., \& Mustiningsih, M. (2020). Perbedaan Tingkat Kinerja Ditinjau dari Jenis Kelamin Pegawai Tata Usaha di Perguruan Tinggi. Jurnal Administrasi Dan Manajemen Pendidikan, 3 (3), hal. 233-238. https://doi.org/10.17977/um027v3i32020p233.

Asmara Indahingwati, Aan Aswari, Ahmad Firman, Aditya Halim Perdana Kusuma Putra, Ansir Launtu, \& Hasmin Tamsah. (2019). How Digital 
Technology Driven Millennial Consumer Behaviour in Indonesia. Journal of Distribution Science, 17 (8), hal. 25-34. https://doi.org/10.15722/jds.17.8.201908.25.

Ayu Yuliantini, P., Putra Astika, I. B., \& Badera, D. N. (2017). Pengaruh Kompetensi Sumber Daya Manusia, Motivasi dan Lingkungan Kerja pada Komitmen Organisasi dan Implikasinya pada Kinerja Pengurus Barang Pemerintah Kabupaten Tabanan. E-Jurnal Ekonomi Dan Bisnis Universitas Udayana, 6 (10), 3697-3730. https://doi.org/10.24843/eeb.2017.v06.i10.p10.

Bastian, Indra. (2007). Akuntansi untuk LSM dan Partai Politik. Jakarta: Erlangga.

Ben Salem, A., \& Lakhal, L. (2018). Entrepreneurial coaching: how to be modeled and measured?. Journal of Management Development, 37:1, pp. 88-100. https:/ / doi.org/10.1108/JMD-12-2016-0292.

Diamantidis, A. D., \& Chatzoglou, P. (2019). Factors affecting employee performance: an empirical approach. International Journal of Productivity and Performance Management, 68:1, pp. 171-193. https:/ / doi.org/10.1108/IJPPM01-2018-0012.

Elbadiansyah. (2019). Manajemen Sumber Daya Manusia. Purwokerto: CV. Irdh.

Ghozali, Imam. (2016). Aplikasi Analisis Multivariate dengan Program SPSS. (Edisi Ke 4). Semarang: Badan Penerbit Universitas Diponegoro.

Halid, S., Choo, H. C., \& Salleh, K. (2015). Intellectual capital management and sustainable competitive advantage: A proposed model for Malaysian PLCs. Proceedings of the International Conference on Intellectual Capital, Knowledge Management and Organisational Learning, ICICKM, 2015-Janua, pp. 355-362.

Hidayah, N., \& Nurbaiti, B. (2019). Pengaruh Pendelegasian Wewenang, Kompensasi Insentif dan Disiplin Kerja Terhadap Produktivitas Kerja di PT. Dewi Permata Perkasa. Jurnal Manajemen Dan Bisnis, 9 (1), hal. 78-99. http://jurnal.untirta.ac.id/index.php/jsm/article/download/6230/4846.

Hasanuddin. (2017). Biopsikologi Pembelajaran : Teori dan Aplikasi. Banda Aceh: Syiah Kuala University Press.

Hira Maulida, U. R. (2020). Effect of Competence and Career Development on Turnover and It's Impact on Productivity. Jurnal Manajemen, 24 (1), hal. 5973. https:// doi.org/10.24912/jm.v24i1.618.

Ikatan Akuntan Indonesia. (2016). Kode Etik Akuntan Profesional. Ikatan Akuntan Indonesia, $1-54$. http://www.iaiglobal.or.id/v03/files/file_berita/KODE_ETIK_2016.pdf.

Irawati, D., \& Martanti, D. E. (2017). Transparasi Pengelolaan Laporan Keuangan BUMDes terhadap Pelaporan Aset Desa (Studi Fenomenologi Pada BUMDes Desa Karangbendo Kec Ponggok Kab Blitar). Prosiding Seminar Nasional Dan Call For Paper Ekonomi Dan Bisnis, 2017, hal. 41-51.

Iskandar, D. (2018). Strategi Peningkatan Kinerja Perusahaan Melalui Pengelolaan Sumber Daya Manusia Dan Kepuasan Kerja Dan Dampaknya Terhadap Produktivitas Karyawan. Jurnal Ilmiah Bisnis Dan Ekonomi Asia, 12 (1), hal. 23-31. https:// doi.org/10.32812/jibeka.v12i1.8.

Jamaludin, \& Pawirosumarto, S. (2017). Pengaruh Kompetensi, Motivasi Kerja dan Disiplin Kerja terhadap Kinerja Guru (Studi Kasus di SMK Karya Fajar 
Kecamatan Petir Kabupaten Serang Provinsi Banten). Swot, 7 (2), hal. 239256.

Klarner, P., Sarstedt, M., Hoeck, M., \& Ringle, C. M. (2013). Disentangling the effects of team competences, team adaptability, and client communication on the performance of management consulting teams. Long Range Planning, 46:3, pp. 258-286. https://doi.org/10.1016/j.lrp.2013.03.001.

Konrad, T., Wiek, A., \& Barth, M. (2021). Learning Processes for Interpersonal Competence Development in Project-Based Sustainability Courses - Insights from a Comparative International Study. International Journal of Sustainability in Higher Education, 22:3, pp. 535-560. https://doi.org/10.1108/IJSHE-072020-0231.

Lutfi Anggraeni. (2015). Pengaruh Kompetensi dan Independensi Terhadap Kinerja Pegawai dengan Komitmen Organisasi sebagai Variabel Intervening, Jurnal Ilmiah Mahasiswa Manajemen, Bisnis dan Akuntansi, 2 (2), hal. 1-28.

Margaretha, H. A., \& Nababan, M. N. (2020). Perancangan Sistem Informasi manajemen Keauangan Berbasis Web Studi Kasus PT. Karya Swadaya Abadi. Jurnal Sains Dan Teknologi, 1 (2), hal. 24-31.

Marzuki, S., \& Wair, F. Y. (2020). Kinerja Operator dan Kehandalan Alat HMC Terhadap Produktivitas Bongkar Muat Curah Kering. Majalah Ilmiah Bahari Jogja, 18 (1), hal. 23-36. https:/ / doi.org/10.33489/mibj.v18i1.226.

Mogot, H. Y., Kojo, C., \& Lengkong, V. P. K. (2019). Pengaruh Gaya Kepemimpinan, Etos Kerja, Kompetensi dan Disiplin Kerja terhadap Kinerja Karyawan pada PT. PLN Cabang Manado. Jurnal EMBA: Jurnal Riset Ekonomi, Manajemen, Bisnis Dan Akuntansi, 7 (1), hal. 881-890. https://doi.org/10.35794/emba.v7i1.22915

Nguyen, P. T., Yandi, A., \& Mahaputra, M. R. (2020). Factors That Influence Employee Performance: Motivation, Leadership, Environment, Culture Organization, Work Achievement, Competence and Compensation (a Study of Human Resource Management Literature Studies). Dinasti International Journal of Digital Business Management, 2:1, pp. 14-40.

Nugroho, T. A. (2020). Evaluasi Struktur Organisasi pada Lembaga Pemasyarakatan Terbuka Terhadap Pelaksanaan Tugas dan Fungsi. Jurnal Ilmiah Kebijakan Hukum, 14 (1), hal. 43-60. https:// doi.org/10.30641/ kebijakan.2020.v14.43-60.

Pitriyani, P., \& Halim, A. (2020). Pengaruh Pengalaman Kerja, Latar Belakang Pendidikan dan Kompensasi terhadap Kinerja Karyawan pada PT. Pegadaian Persero Cabang Rantauprapat. Ekonomi Bisnis Manajemen dan Akuntansi, 1 (1). hal. 60-68. https:// doi.org/10.36987/ebma.v1i1.1900.

Rani, F. K. G., Lambey, L., \& Pinatik, S. (2018). Pengaruh Integritas, Kompetensi, dan Profesionalisme terhadap Produktivitas Kerja Karyawan Bagian Akuntansi pada PT. Bank Mandiri (Persero) Tbk Manado. Going Concern : Jurnal Riset Akuntansi, 13 (3), hal. 41-51. https://doi.org/10.32400/gc.13.03.19942.2018.

Riyanto, Selamet., \& Hatmawan, A. A. (2020). Metode Riset Penelitian Kuantitatif. Yogyakarta: CV Budi Utama. 
Rotana Chahtli \& Noshaba Batool, U. J. (2021). Impact of Training and Development on Employeesee Perceived Performance and Productivity. The Indian Economic Journal, 18:14, pp. 688-697. https://doi.org/10.1177/0019466220150308.

Saifuddin, Ahmad. (2020). Penyusunan Skala Psikologi. Jakarta: Kencana.

Suarna, I. P. B., \& Suartana, I. W. (2019). Pengaruh Gaya Kepemimpinan Transformasional dan Budaya Tri Hita Karana pada Kinerja LPD. E-Jurnal Akuntansi, 29(2), hal. 818-832.

Supriyanto, A. S., Ekowati, V. M., Pujianto, Z. T., \& Masyhuri. (2021). Employee Engagement: A Quantitative Review and Its Relationship with Job Satisfaction and Employee Performance. Proceedings of the International Conference on Engineering, Technology and Social Science (ICONETOS 2020), 529: Iconetos 2020, p. 268-273. https://doi.org/10.2991/assehr.k.210421.038.

Supriyono, R. A. (2018). Akuntansi Keperilakuan. Yogyakarta: Gadjah Mada University Press.

Swandari, N. K. A. S., Setiawina, N. D., \& Marhaeni, A. A. I. N. (2017). Analisis Faktor-Faktor Penentu Kinerja Karyawan Bumdes di Kabupaten Jembrana. Jurnal Ekonomi Dan Bisnis, 6(4), hal. 1365-1394. https://ojs.unud.ac.id/index.php/EEB/article/view/24184.

Tumiwa, A., Tewal, B., \& Palandeng, I. D. (2017). The Influence of Information Thecnology, Work Environtment, and Competence on Employee Productivity. (Case Study On Central Office Of Bank Sulutgo). Jurnal EMBA, 5 (3), pp. 3895-3904. http://www.jurnalemba.ac.id.

Undang-Undang Republik Indonesia Nomor 6 Tahun 2014 tentang Desa.

Vveinhardt, J., Bendaraviciene, R., \& Vinickyte, I. (2019). Mediating factor of emotional intelligence in intercultural competence and work productivity of volunteers. Sustainability (Switzerland), 11:9, pp. 1-21. https://doi.org/10.3390/su11092625.

Wahyuningsih, S. (2019). Pengaruh Pelatihan Dalam Meningkatkan Produktivitas Kerja Karyawan. Jurnal Warta, 6, hal. 1829-7463.

Wibowo, T. S., Badi'ati, A. Q., Annisa, A. A., Wahab, M. K. A., Jamaludin, M. R., Rozikan, M., Mufid, A., Fahmi, K., Purwanto, A., \& Muhaini, A. (2020). Effect of Hard Skills, Soft Skills, Organizational Learning and Innovation Capability on Islamic University Lecturers' Performance. Systematic Reviews in Pharmacy, 11(7), pp. 556-569. https://doi.org/10.31838/srp.2020.7.80.

Wirawan, Putu Eka., \& Antara, Made., (2017). Magang Kerja di Hotel Amerika Serikat. Denpasar: Pelawa Sari ). 